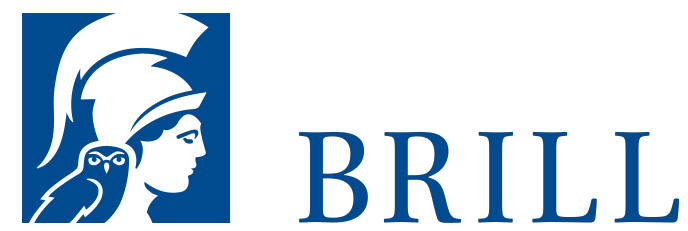

\title{
Unterwegs zum Roman
}

Novalis' Werdegang als Übergang von der Philosophie zur Poesie

Author: Yihong Hu

Die vorliegende Studie versucht den geistigen Werdegang des Novalis als ein „Unterwegs zum Roman“ zu verstehen und zugleich seinen Roman "Heinrich von Ofterdingen“ als Poetisierung seines philosophischen Ansatzes zu interpretieren. Die Arbeit schlägt einen Abgleich von Poesie und Philosophie vor und untersucht Novalis' Roman „Heinrich von Ofterdingen“, der nicht zu unrecht als exemplarischer "romantischer Roman“ bezeichnet wird, unter dem Aspekt, dass der Werdegang Novalis' als ein Übergang von der Philosophie zur Poesie zu erfassen sei. Die These soll sein, dass die Genese seiner Philosophie, insbesondere seine philosophischen Überlegungen in den Fichte-Studien (1794/5), als die Herausbildung der Romantheorie und als der eigentliche Inhalt des Romans gelesen werden muss. Ziel der Arbeit ist es, den in der Romantik zunehmend zur Philosophie in Konkurrenz tretenden Poesiebegriff, wie er sich dichterisch und philosophisch in Novalis „Heinrich von Ofterdingen“ als „wahrhafter Idealismus“ manifestiert, von seinen philosophischen Voraussetzungen her zu erklären.

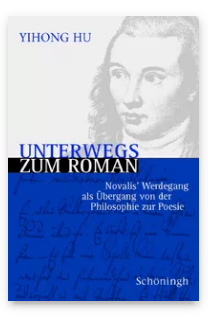

Pages: 222

Seiten

Language:

German

Subjects:

German,

Literature and

Cultural Studies

Publisher: Brill |

Schöningh

E-Book (PDF)

Released online:

29 Jan 2020

ISBN: 978-3-

657-75744-2

List price

USD $\$ 30.00$

Paperback

Publication date:

20 Mar 2007

ISBN: 978-3-

5०6-75744-9

List price

USD $\$ 30.00$ 
For more information see brill.com

Order information: Order online at brill.com +44330 333 0049 | customerservices@brill.com Submission information: brill.com/authors

Titles published by Brill | Fink, Brill | mentis or Brill | Schöningh: +49(o)715413279216| brill@brocom.de 